\title{
EFFECT OF WATER ON EXPANSIONS OF CERAMIC BODIES OF DIFFERENT COMPOSITION
}

\author{
By H. G. Schurecht and G. R. Pole ${ }^{1}$
}

ABSTRACT

The effects of the composition of some ceramic bodies on their moisture expansions were investigated. With the exception of mixtures containing blast-furnace slag or magnesite, most bodies with high absorptions developed considerable expansion. Bodies with low absorptions composed of pure clay and feldspar developed practically no moisture expansion, while those composed of clay, feldspar, and more than 20 per cent silica developed considerable moisture expansion. By adding magnesite the resistance of a ceramic body to moisture expansion was improved. Additions of whiting, iron oxide, and titanium oxide were not as beneficial as magnesite. It was found that crazing caused by moisture expansion of bodies can usually be prevented by proper manufacturing control.

CONTENTS

I. Introduction

II. Experimental methods

III. Effects of silica

IV. Effects of blast-furnace slag and feldspar

V. Moisture expansions of clay, feldspar, and flint mixtures._._._._. 337

VI. Effects of iron oxide, calcium carbonate, magnesium carbonate, and titanium oxide.......

VII. Summary and conclusions 341

\section{INTRODUCTION}

It has been shown ${ }^{2}$ that a type of delayed crazing found on glazed ceramic ware may, in certain cases, be caused by a gradual expansion of the body during storage or use produced by the action of moisture while the glaze generally does not expand in the same manner. This type of expansion may be called "moisture expansion" to distinguish it from other types. It has, furthermore, been shown in the publication referred to above that expansions of ceramic bodies similar in magnitude to those obtained during long periods of storage may be produced by subjecting them to steam at a pressure of $150 \mathrm{lbs}$./in. ${ }^{2}$ for one hour in an autoclave. This treatment was, therefore, suggested as an accelerated test for indicating whether crazing from this expansion will develop in time on ceramic bodies.

\footnotetext{
1 Research associates of the National Terra Cotta Society at the National Bureau of Standards.

2 Methods for Testing Crazing of Glazes Caused by Increases in Size of Ceramic Bodies, J. Am. Cer. Soc.,
} 11, pp. 271-277; 1928. 
In general, this type of crazing is less apt to occur on vitreous than on porous bodies, although it may develop on some vitreous bodies. This led to the belief that it may depend upon the composition of the body as well as the degree of vitrification. Studies were made, therefore, to determine the effects of additions of different substances to ceramic bodies upon their expansions when treated with water or steam. It was found that the expansion of the body depends upon the mineral and chemical composition of the body as well as its absorption and therefore can be reduced and often prevented by proper manufacturing control. The results of the investigations warranting this conclusion are given below.

\section{EXPERIMENTAL METHODS}

To determine the moisture expansions of the bodies, bars 24 inches long were fired to cone 6 . This firing would drive off any combined water which might be present. Shortly after firing and cooling to $20^{\circ} \mathrm{C}$. their lengths were measured by means of a microscopic comparator. ${ }^{3}$ They were then completely immersed in water for 168 hours, after which their lengths were measured while wet and also after drying at $110^{\circ} \mathrm{C}$. for 12 hours. The same specimens were then kept immersed under water for 240 and 312 hour periods, and their wet lengths were measured after each soaking period. They were dried at $110^{\circ} \mathrm{C}$. for 20 hours, and their dry lengths at $20^{\circ} \mathrm{C}$. were measured. The specimens were then boiled in water 4 hours, after which their wet and dry lengths were again measured. Their lengths were also determined at $20^{\circ} \mathrm{C}$. subsequent to subjecting them to steam at pressures of 75, 100, and $125 \mathrm{lbs}$./in. ${ }^{2}$ for 1 hour. All absorption tests were made by 5 hours, boiling in water.

\section{EFFECTS OF SILICA}

The mixtures given in Table 1 were used to study the effects of silica on the moisture expansions of several types of ceramic bodies. The average percentages moisture expansion, measured and computed as the per cent linear expansion, in terms of the original dry lengths of the open-burning bodies with and without free silica added are shown in Figure 1. These values represent the averages obtained on two specimens in each case. It is apparent that the openburning "pure clay" " body, which expanded considerably due to the action of water, expanded decidedly more after the addition of 40 per cent silica. Drying the specimens which have been immersed under water often increased their lengths. Heating the wet.specimens during drying probably causes the water to react with the

${ }^{3}$ See footnote 2, p. 1.

4 By "pure clay" is meant high-grade commercial clays, such as ball clays and kaolins, containing less than 5 per cent free silica. 
body. After the specimens have been boiled or treated in an autoclave, however, they contract instead of expand upon drying. Why this obtains remains to be explained. From Figure 2 it can be seen that the addition of silica increased the moisture expansion of tightburning pure clay bodies to a greater extent than it did open-burning pure clay bodies. For example, the tight-burning pure clay body developed practically no expansion when treated in the autoclave, but with 40 per cent silica it expanded about 0.065 per cent.

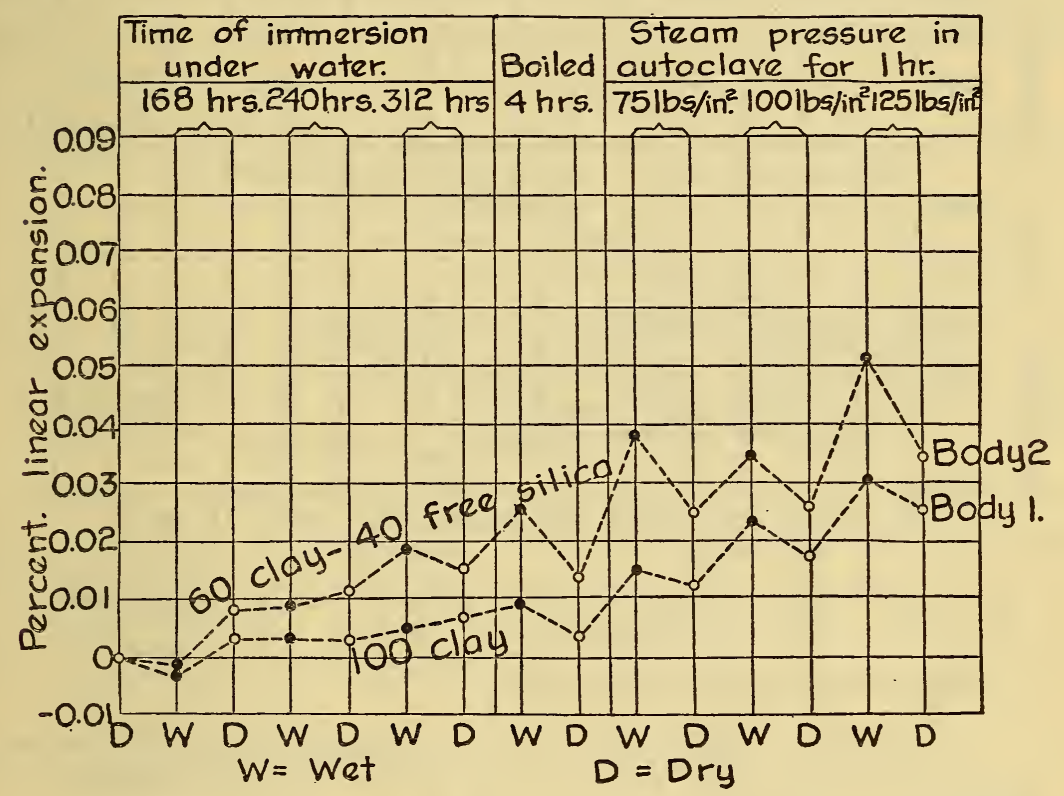

FigURE 1.-Effect of crystalline silica on changes in size of an open-burning pure clay due to water treatments

TABLE 1.-Composition of ceramic bodies containing varying amounts of clay and free silica

\begin{tabular}{|c|c|c|c|c|c|c|c|c|c|c|}
\hline \multirow{2}{*}{$\begin{array}{l}\text { Body } \\
\text { No.1 }\end{array}$} & \multicolumn{4}{|c|}{ Bonding portion of body } & \multicolumn{3}{|c|}{ Composition of cone 6 grog } & \multicolumn{2}{|c|}{$\begin{array}{l}\text { Clay and free } \\
\text { silica in terms of } \\
\text { total weight }\end{array}$} & \multirow{2}{*}{$\begin{array}{c}\text { Absorp- } \\
\text { tion } \\
\text { after } 5 \\
\text { hours, } \\
\text { boiling }\end{array}$} \\
\hline & $\begin{array}{c}\text { English } \\
\text { ball } \\
\text { clay }\end{array}$ & $\begin{array}{c}\text { Florida } \\
\text { kaolin }\end{array}$ & $\begin{array}{c}\text { Potter's } \\
\text { flint } \\
\text { (quartz- } \\
\text { ite) }\end{array}$ & $\begin{array}{c}\text { Diato- } \\
\text { maceous } \\
\text { silica }\end{array}$ & $\begin{array}{c}\text { English } \\
\text { ball } \\
\text { clay }\end{array}$ & $\begin{array}{l}\text { Florida } \\
\text { kaolin }\end{array}$ & $\begin{array}{c}\text { Potter's } \\
\text { flint } \\
\text { (quartz- } \\
\text { ite) }\end{array}$ & Clay & $\begin{array}{l}\text { Free } \\
\text { silica }\end{array}$ & \\
\hline & \begin{tabular}{c|}
19.5 \\
9.75 \\
65.0 \\
39.0 \\
5.0 \\
20.0 \\
17.5
\end{tabular} & $\begin{array}{c}45.5 \\
29.25 \\
\end{array}$ & $\begin{array}{r}26.0 \\
-26.0 \\
95.0 \\
80.0\end{array}$ & 82.5 & $\begin{array}{c}10.5 \\
5.25 \\
35.0 \\
21.0\end{array}$ & $\begin{array}{l}24.5 \\
15.75\end{array}$ & $\begin{array}{r}14.0 \\
14.0 \\
-0\end{array}$ & $\begin{array}{c}\text { Per cent } \\
100 \\
60 \\
100 \\
60 \\
5 \\
20 \\
17.5\end{array}$ & \begin{tabular}{|c|} 
Per cent \\
40 \\
40 \\
95 \\
80 \\
82.5
\end{tabular} & $\begin{array}{r}\text { Per cent } \\
14.8 \\
19.6 \\
.7 \\
10.3 \\
16.8 \\
15.2\end{array}$ \\
\hline
\end{tabular}

1 The first 4 bodies will be designated as follows in this report: (1) Open-burning clay, (2) open-burning siliceous clay, (3) tight-burning clay, and (4) tight-burning siliceous clay.

$59791^{\circ}-29-10$ 
It appears, therefore, that the tendency of ceramic bodies to develop moisture expansion may be decreased by selecting clays low in quartzite, which is generally the most common form of free silica

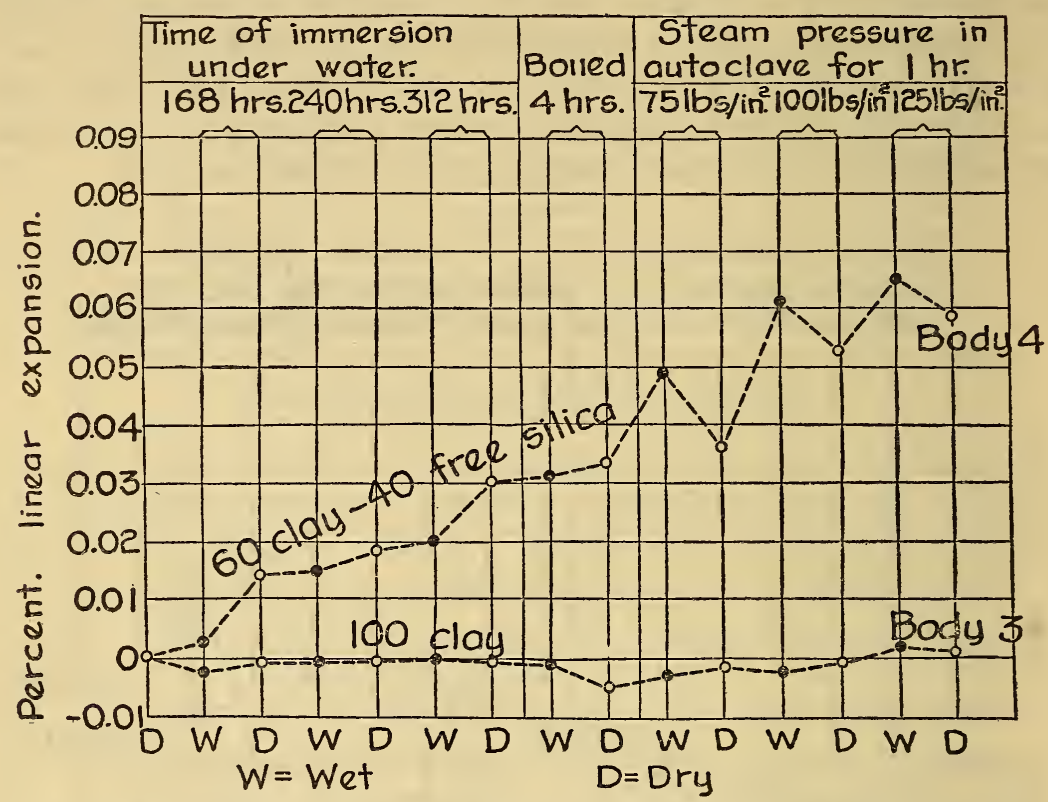

FIGURE 2.-Effect of crystalline silica on changes in size of a tight-burning pure clay due to water treatments

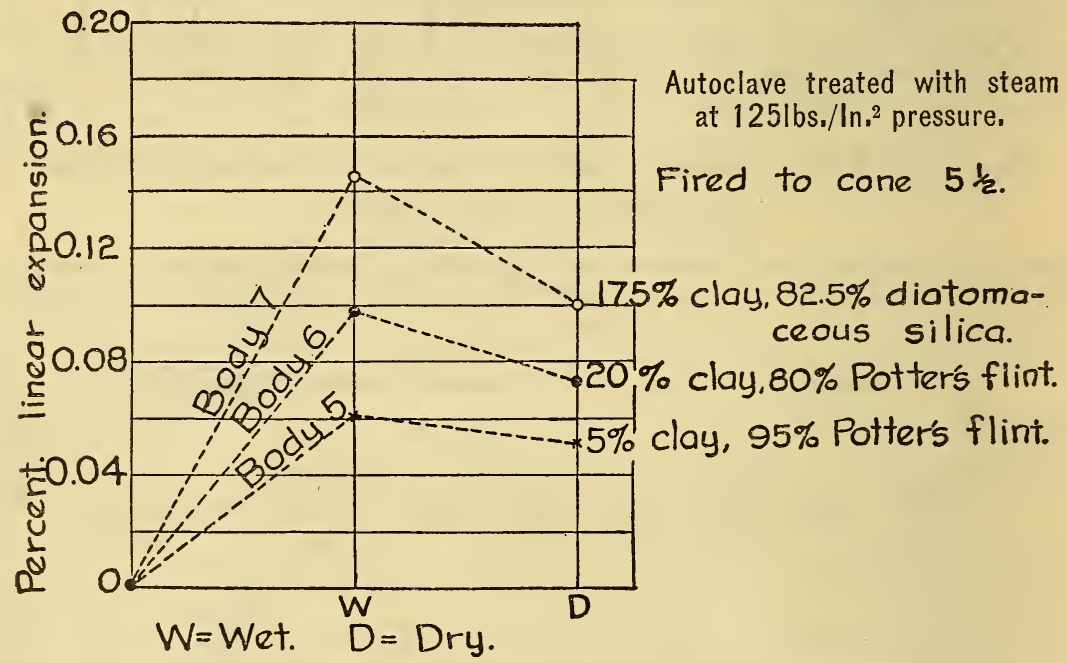

Figure 3.-Expansions of diatomaceous silica and potter's fint when mixed with small percentages of clay

in clays. It is evident from the results shown in Figure 3 that amorphous silica, such as diatomaceous silica, may increase the moisture expansion to a greater extent than quartzite, but this form 
of silica is seldom found in large amounts in clays, such as are used for making burned clay products. This may be due to the fact that diatomaceous silica is more colloidal in nature than quartzite.

\section{EFFECTS OF BLAST-FURNACE SLAG AND FELDSPAR}

The effects of blast-furnace slag and feldspar additions on the moisture expansions of some bodies containing grog were determined after firing to different temperatures the bodies whose compositions are given in Table 2. The results are given in Table 2 and plotted in Figures 4 and 5.

TABLE 2.-Moisture expansions and absorptions of bodies containing blast-furnace slag and feldspar after being fired to different temperatures

\begin{tabular}{|c|c|c|c|c|c|c|c|c|c|c|}
\hline \multirow{3}{*}{ No. } & \multirow{3}{*}{ Composition } & \multicolumn{3}{|c|}{ Fired to cone 4} & \multicolumn{3}{|c|}{ Fired to cone 6} & \multicolumn{3}{|c|}{ Fired to cone 8} \\
\hline & & \multicolumn{2}{|c|}{$\begin{array}{c}\text { Expansion } \\
\text { after treatment } \\
\text { in autoclave } \\
\text { at } 150 \text { lbs./in. } \\
\text { for } 1 \text { hour }\end{array}$} & \multirow{2}{*}{$\begin{array}{l}\text { A bsorp- } \\
\text { tion } \\
\text { after } \\
5 \text { hours } \\
\text { boiling }\end{array}$} & \multicolumn{2}{|c|}{$\begin{array}{l}\text { Expansion } \\
\text { after treatment } \\
\text { in autoclave } \\
\text { at } 150 \mathrm{lbs} . / \mathrm{in} .^{2} \\
\text { for } 1 \text { hour }\end{array}$} & \multirow{2}{*}{$\begin{array}{l}\text { A bsorp- } \\
\text { tion } \\
\text { after } \\
5 \text { hours } \\
\text { boiling }\end{array}$} & \multicolumn{2}{|c|}{$\begin{array}{l}\text { Expansion } \\
\text { after treatment } \\
\text { in autoclave } \\
\text { at } 150 \text { lbs./in. }{ }^{2} \\
\text { for } 1 \text { hour }\end{array}$} & \multirow{2}{*}{$\begin{array}{l}\text { A bsorp } \\
\text { tion } \\
\text { after } \\
5 \text { hours } \\
\text { boiling }\end{array}$} \\
\hline & & Wet & Dry & & Wet & Dry & & Wet & Dry & \\
\hline & 65 per cent clay, 135 & $\begin{array}{c}\text { Per cent } \\
0.0895\end{array}$ & $\begin{array}{c}\text { Per cent } \\
0.0737\end{array}$ & $\begin{array}{c}P e r \text { cent } \\
15.4\end{array}$ & $\begin{array}{c}\text { Per cent } \\
0.0574\end{array}$ & $\begin{array}{c}\text { Per cent } \\
0.0527\end{array}$ & $\begin{array}{c}\text { Per cent } \\
14.0\end{array}$ & $\begin{array}{c}\text { Per cent } \\
0.0464\end{array}$ & $\begin{array}{c}\text { Per cent } \\
0.0443\end{array}$ & $\begin{array}{r}\text { Per cent } \\
12.6\end{array}$ \\
\hline B. & $\begin{array}{l}\text { per cent grog. } \\
60 \text { per cent clay, } 22.5 \\
\text { per cent grog, } 17.5 \\
\text { per ce ent s lag, } \\
\text { through } 80 \text { mesh. }\end{array}$ & .0182 & .0149 & 12.4 & .0099 & .0107 & 11.3 & .0052 & .0035 & 8.1 \\
\hline C. & $\begin{array}{l}65 \text { per cent clay, } 17.5 \\
\text { per cent grog, } 17.5 \\
\text { per ce nt s l a g, } \\
\text { through } 10 \text { mesh. }\end{array}$ & .0339 & .0283 & 12.6 & .0124 & .0103 & 11.3 & .0070 & .0069 & 10.1 \\
\hline D. & $\begin{array}{l}60 \text { per cent clay, } 22.5 \\
\text { per cent grog, } 17.5 \\
\text { per cent feldspar, } \\
\text { through } 80 \text { mesh. }\end{array}$ & .1204 & .0994 & 8.2 & .0464 & .0425 & 5.9 & .0430 & .0381 & 5.0 \\
\hline E.. & $\begin{array}{l}65 \text { per cent clay, } 17.5 \\
\text { per cent grog, } 17.5 \\
\text { per cent feldspar, } \\
\text { through } 10 \text { mesh. }\end{array}$ & .1119 & .0899 & 9.2 & .0594 & .0528 & 6.4 & .0540 & .0513 & 5.1 \\
\hline
\end{tabular}

1 The clay used in these bodies was a No. 2 fire clay, and the grog employed was calcined fire clay ground to pass through a 10 -mesh sieve.

It was found that the addition of a blast-furnace slag to the body decreased its moisture expansion to a marked degree. The addition of feldspar in a few cases reduced this expansion only slightly, whereas in most. cases it was increased. As a rule, the bodies containing 80-mesh as compared to 10-mesh feldspar showed lower expansion. More intimate mixtures can be obtained with finely ground material. The reverse is true with low-fired bodies, the reason for which remains to be determined.

Increasing the firing temperature of all bodies from cone 4 to cones 6 and 8 and thereby reducing their absorptions also reduced the moisture expansions. There is, however, apparently no direct relation (fig. 5) between absorptions and moisture expansions of bodies of 
different compositions. For example, bodies containing feldspar have comparatively low absorptions but develop relatively high moisture expansions, whereas bodies with blast-furnace slag may have much

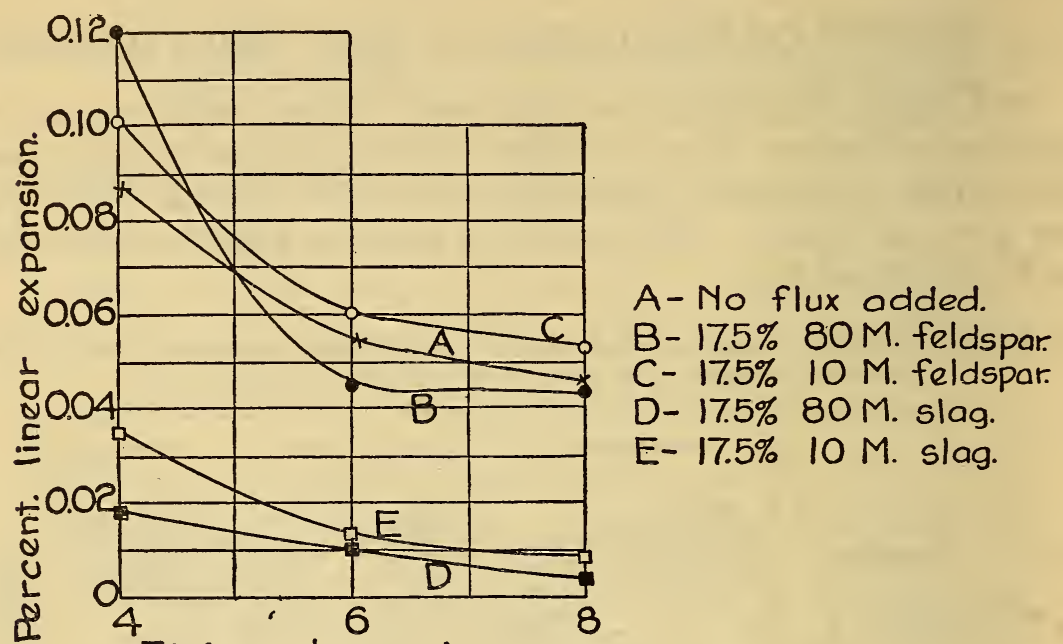

Firing temp. in cones.

FIGURE 4.-The effects of feldspar and slag additions to a clay body on its expansion due to autoclave treatment after firing to different temperatures

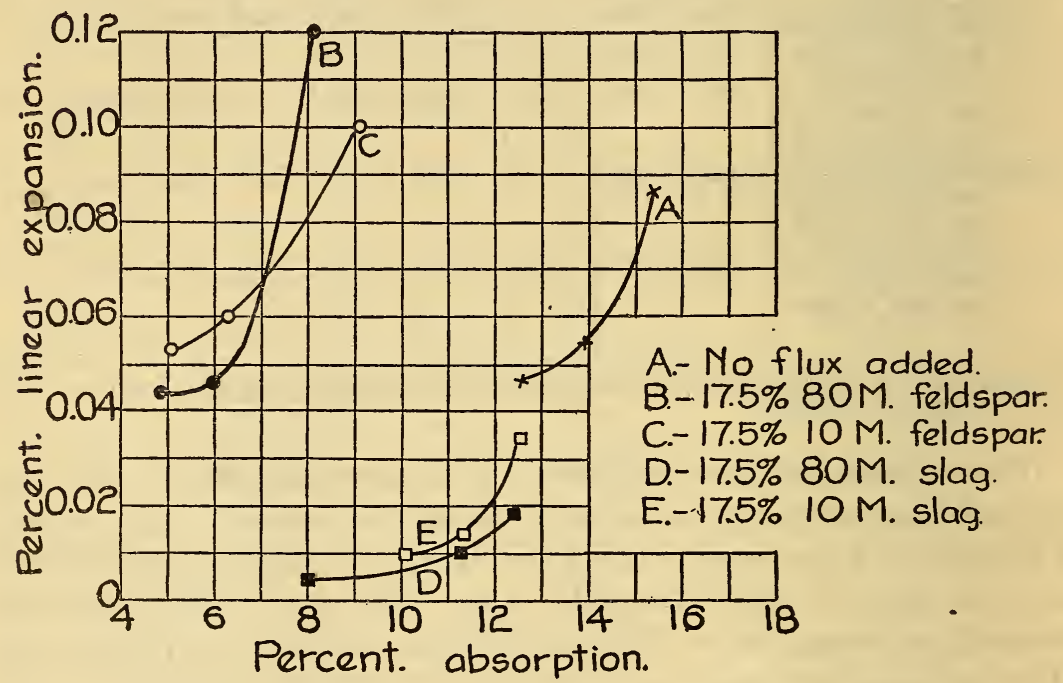

FIGURE 5.-The relation between absorptions and expansions of some bodies due to autoclave treatments

higher absorptions but still develop lower moisture expansions. For bodies having the same compositions, however, the moisture expansion increases with an increase in absorption, 


\section{MOISTURE EXPANSIONS OF CLAY, FELDSPAR, AND FLINT MIXTURES}

The moisture expansions of the mixtures given in Table 3 containing varying amounts of clay, feldspar, and potter's flint were determined after immersing the specimens in water 40 hours and boiling in water 2 hours, and also after treating them in an autoclave at $150 \mathrm{lbs} . /$ in. $^{2}$ steam pressure for 1 hour. The results are given in Table 3 and are plotted in Figures 6 and 7.

TABLE 3.-The moisture expansions of clay, feldspar, and fint mixtures after having been fired to cone $5 \frac{1}{2}$

\begin{tabular}{|c|c|c|c|c|c|c|c|}
\hline \multirow{3}{*}{ Body No. } & \multicolumn{3}{|c|}{ Composition } & \multicolumn{3}{|c|}{ Expansion } & \multirow{3}{*}{$\begin{array}{l}\text { Absorp- } \\
\text { tion after } \\
5 \text { hours' } \\
\text { boiling }\end{array}$} \\
\hline & \multirow{2}{*}{$\begin{array}{l}\text { Tennessee } \\
\text { No. } 5 \\
\text { ball clay }\end{array}$} & \multirow{2}{*}{$\begin{array}{l}\text { Maine } \\
\text { feldspar }\end{array}$} & \multirow{2}{*}{$\begin{array}{l}\text { Potter's } \\
\text { flint } \\
\text { quartzite }\end{array}$} & \multirow{2}{*}{$\begin{array}{l}\text { Soaked in } \\
\text { water } \\
40 \text { hours, } \\
\text { boiled } \\
2 \text { hours, } \\
\text { and dried } \\
\text { at } 110^{\circ} \mathrm{C} \text {. }\end{array}$} & \multicolumn{2}{|c|}{$\begin{array}{l}\text { Treated in an autoclave } \\
\text { at } 150 \mathrm{lbs} \text {. } / \text { in. } .^{2} \text { steam } \\
\text { pressure for } 1 \text { hour }\end{array}$} & \\
\hline & & & & & Wet & Dry & \\
\hline & $\begin{array}{r}100 \\
80 \\
80 \\
60 \\
60 \\
60\end{array}$ & \begin{tabular}{c|}
20 \\
-40 \\
20
\end{tabular} & $\begin{array}{l}20 \\
20 \\
40\end{array}$ & $\begin{array}{r}\text { Per cent } \\
0.032 \\
.040 \\
.014 \\
-.002 \\
.016 \\
.008\end{array}$ & $\begin{array}{r}\text { Per cent } \\
0.109 \\
.054 \\
.115 \\
.004 \\
.066 \\
.104\end{array}$ & $\begin{array}{r}\text { Per cent } \\
0.063 \\
.067 \\
.078 \\
.000 \\
.062 \\
.066\end{array}$ & $\begin{array}{r}\text { Per cent } \\
5.44 \\
1.51 \\
8.86 \\
.38 \\
3.87 \\
13.45\end{array}$ \\
\hline & $\begin{array}{l}40 \\
40 \\
40 \\
40 \\
20\end{array}$ & $\begin{array}{c}60 \\
40 \\
20 \\
-80 \\
80\end{array}$ & $\begin{array}{l}20 \\
40 \\
60\end{array}$ & $\begin{array}{r}-.004 \\
.011 \\
.002 \\
.011 \\
.004\end{array}$ & $\begin{array}{l}.002 \\
.023 \\
.001 \\
.081 \\
.007\end{array}$ & $\begin{array}{r}-.008 \\
.010 \\
.051 \\
.005\end{array}$ & $\begin{array}{r}.29 \\
.46 \\
3.52 \\
3.28 \\
.18\end{array}$ \\
\hline 12 & $\begin{array}{r}20 \\
20 \\
20 \\
20 \\
5\end{array}$ & $\begin{array}{r}60 \\
40 \\
20 \\
-95\end{array}$ & $\begin{array}{l}20 \\
40 \\
60 \\
80\end{array}$ & $\begin{array}{r}.010 \\
.015 \\
.016 \\
.035 \\
-.009\end{array}$ & $\begin{array}{l}.025 \\
.051 \\
.096 \\
.097 \\
.004\end{array}$ & $\begin{array}{l}.021 \\
.043 \\
.088 \\
.073 \\
.000\end{array}$ & $\begin{array}{r}.20 \\
.97 \\
5.68 \\
15.22 \\
.15\end{array}$ \\
\hline 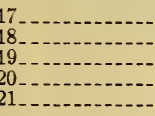 & 5 & $\begin{array}{r}80 \\
60 \\
40 \\
-85 \\
85\end{array}$ & $\begin{array}{l}20 \\
40 \\
60 \\
95 \\
15\end{array}$ & $\begin{array}{l}.011 \\
.011 \\
.040 \\
.016 \\
.010\end{array}$ & $\begin{array}{l}.059 \\
.100 \\
.188 \\
.061 \\
.105\end{array}$ & $\begin{array}{l}.058 \\
.079 \\
.052 \\
.051 \\
.090\end{array}$ & $\begin{array}{r}.41 \\
4.98 \\
13.44 \\
16.80 \\
2.70\end{array}$ \\
\hline
\end{tabular}

It is evident from the results plotted in Figure 6 that the addition of feldspar to "pure clay" materially reduces the moisture expansion of the fired body, whereas the addition of feldspar to siliceous clay reduces the moisture expansion only slightly. They also indicate that a mixture of feldspar and silica may develop a greater moisture expansion than either feldspar or flint alone. This expansion was found to be greatest with a mixture composed approximately of 40 per cent feldspar and 60 per cent flint, indicating a reaction between the flint and silica.

The relations between absorptions and moisture expansions of the mixtures are shown in Figure 7. The moisture expansions of all mixtures with high absorptions are usually large. Of the mixtures with low absorptions, those composed of "pure clay" and feldspar 


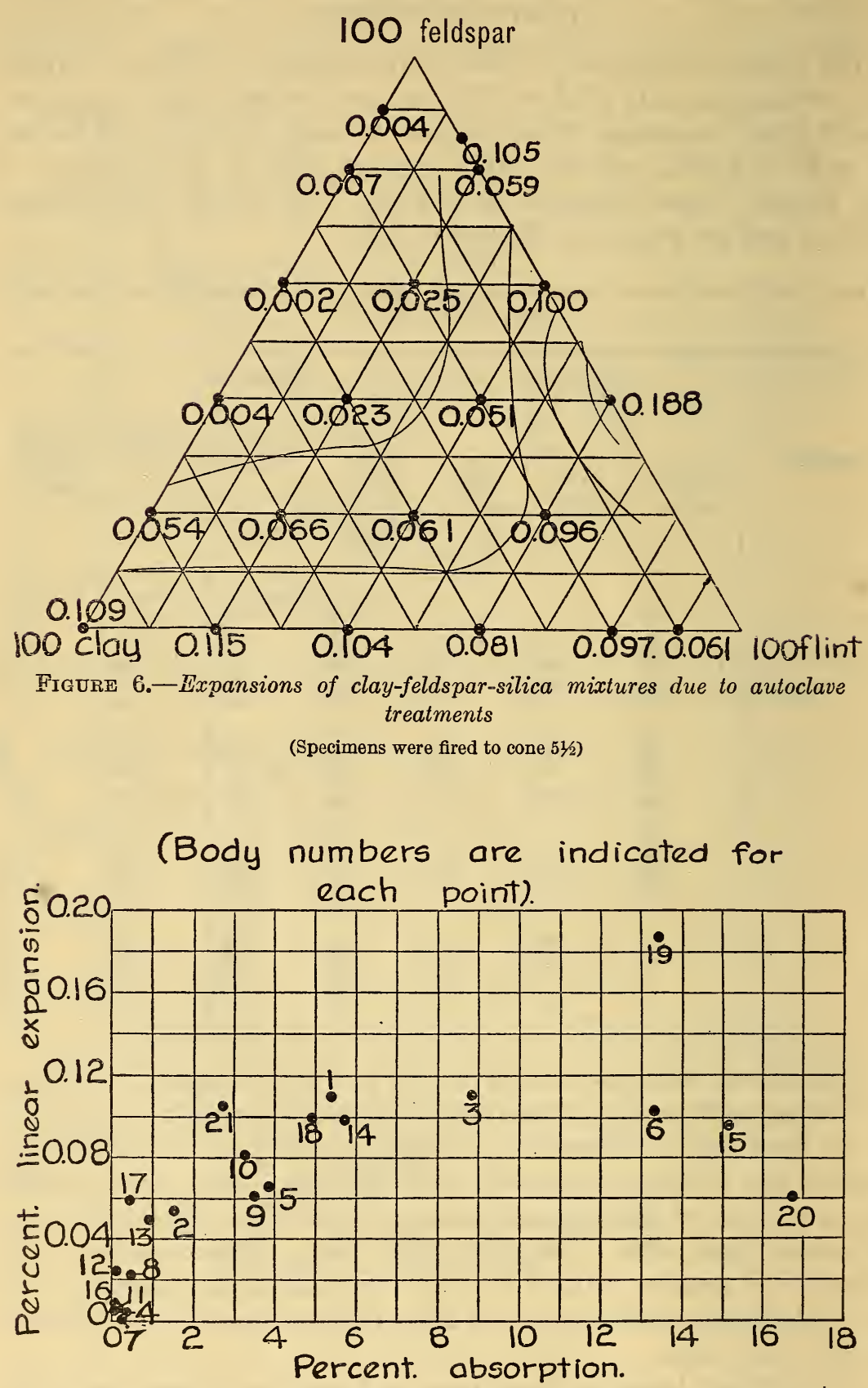

FIGURE 7.-Relations between the absorptions of clay-feldspar-silica and their expansions due to autoclave treatments 
have developed practically no expansion, whereas those composed of clay, silica, and feldspar have developed considerable moisture expansion. Note the difference between clay, silica, and feldspar mixtures, clay, and silica, and clay and feldspar, two component mixtures. (See fig. 6.)

It must be remembered that these bodies were fired to cone $5 \frac{1 / 2}{12}$ and different results would be obtained if they were fired to different temperatures.

\section{EFFECTS OF IRON OXIDE, CALCIUM CARBONATE, MAGNESIUM CARBONATE, AND TITANIUM OXIDE}

The mixtures given in Table 4 were studied to determine the effects of iron oxide, calcium carbonate, magnesium carbonate, and titanium oxide upon the moisture expansions of ceramic bodies. Sufficient magnesium and calcium carbonates were added, as magnesium and whiting, respectively, to the bodies to introduce the equivalents of 5 per cent, respectively, of magnesium and calcium oxides.

It is apparent from the results shown in Table 4 and Figure 8 that finely ground magnesite was most effective for reducing the moisture expansion of this body, since the addition of 10.5 per cent reduced the expansion from 0.097 to 0.011 per cent.

TABLE 4.-The expansions caused by water treatments of bodies containing whiting, magnesite, iron oxide, and titanium oxide

[Specimens were fired to cone 7]

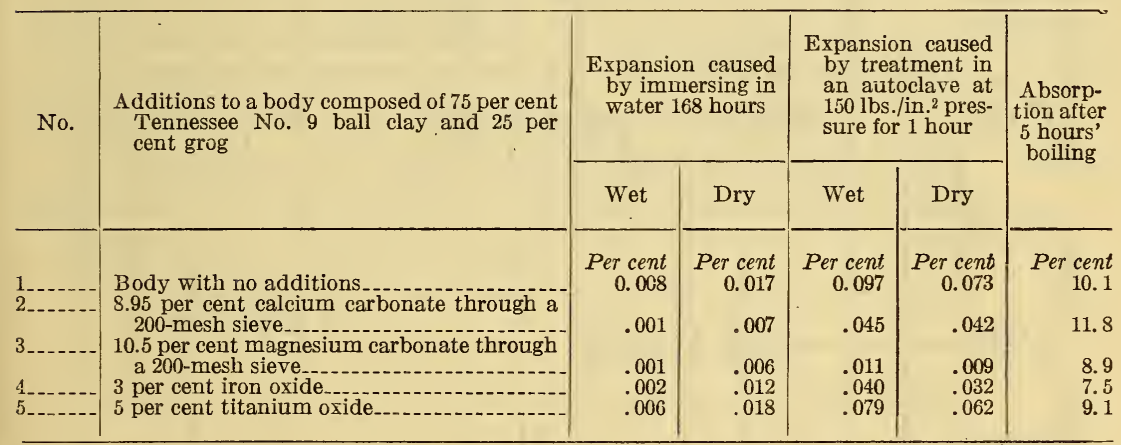

Three per cent iron oxide reduced the expansion caused by autoclave treatment to 0.040 per cent, which is not so effective as the addition of 10.5 per cent magnesite to the body. Adding 8.95 per cent whiting to the body reduced the moisture expansion caused by autoclave treatment to 0.045 per cent. It is also not so effective as magnesite. Adding 5.0 per cent titanium oxide to the body decreased the expansion to 0.079 per cent, being less effective than the other fluxes used. 


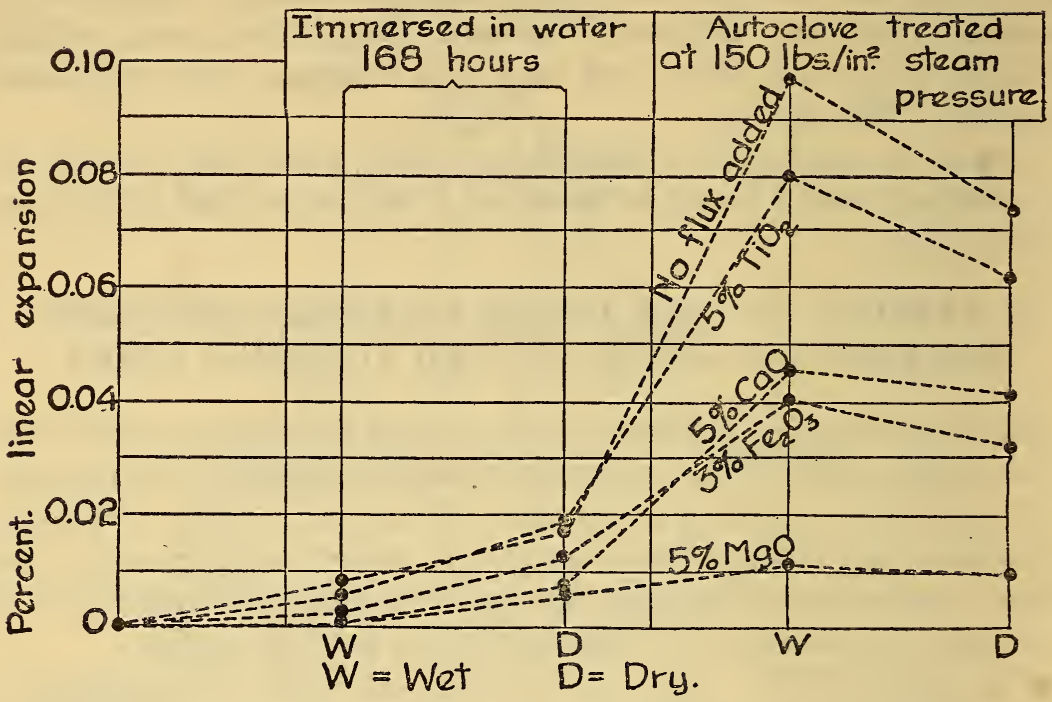

Figure 8.-Effects of $\mathrm{TiO}_{2}, \mathrm{CaO}, \mathrm{Fe}_{2} \mathrm{O}_{3}$, and $\mathrm{MgO}$ additions on the tendency of clay bodies to expand from water treatments

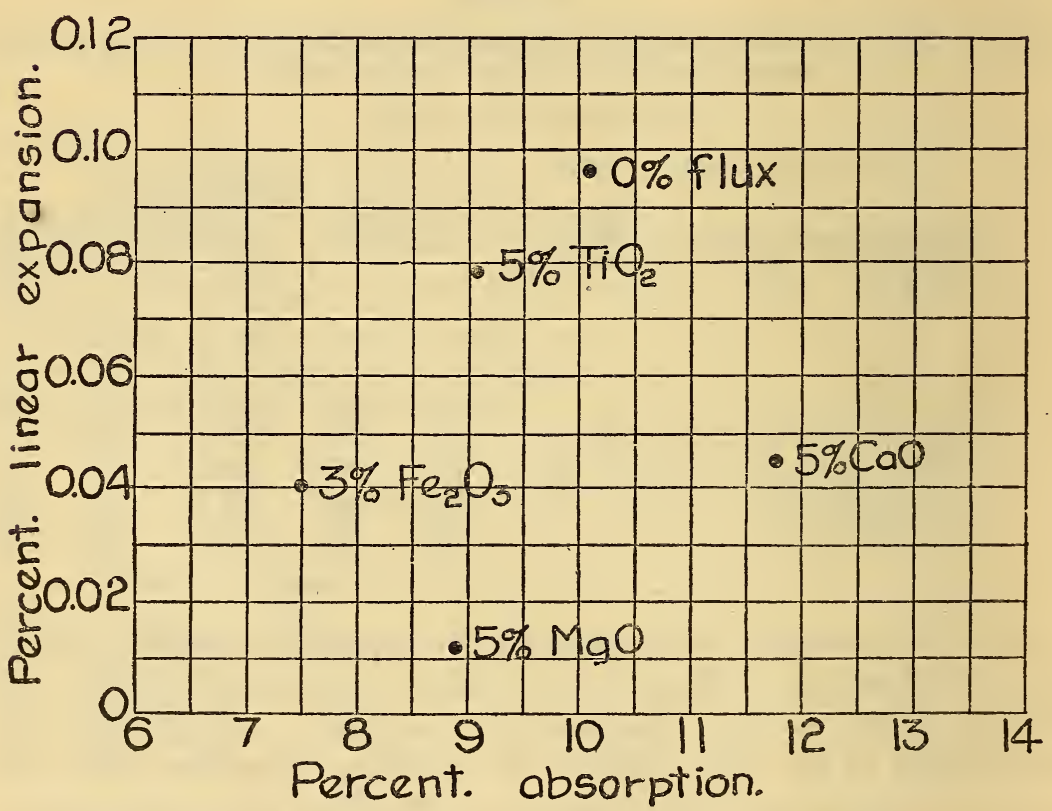

FIgURE 9.-The relation between absorptions and expansions of bodies containing $\mathrm{CaO}, \mathrm{MgO}, \mathrm{Fe}_{2} \mathrm{O}_{3}$, and $\mathrm{TiO}_{2}$ 
The relation between absorptions and moisture expansions of these mixtures is shown in Figure 9. It is evident that the body containing 5 per cent magnesium oxide has a low moisture expansion in spite of the fact that it has a comparatively high absorption, whereas bodies containing the other fluxes have developed relatively high moisture expansions.

It seems evident from these results that by using finely-ground magnesite or dolomite as a flux in place of whiting in ceramic bodies that their resistance to moisture expansion can be improved.

\section{SUMMARY AND CONCLUSIONS}

1. Fired mixtures of "pure clay" and feldspar, with low absorptions, showed comparatively low moisture expansions when subjected to steam at $150 \mathrm{lbs} . /$ in. $^{2}$ pressure for one hour. Similar mixtures with low absorptions, but containing 20 per cent free silica, however, expanded considerably.

2. With the exception of bodies containing slag or magnesite, all others tested having high absorptions developed considerable moisture expansions.

3. The moisture expansion of a siliceous fire-clay body was decreased by the addition of blast-furnace slag, while the expansion was increased in some cases and reduced only slightly in others by the addition of feldspar.

4. By adding finely-ground magnesite to a ball-clay body, the moisture expansion was reduced more than by the addition of whiting, iron oxide, or titanium oxide. The magnesite used was ground to pass a 200-mesh sieve in this case. Coarsely ground magnesite may not be as beneficial as this finely-ground material.

5. Increasing the firing temperature of ceramic bodies reduces their moisture expansion to a marked extent in most cases.

Washington, March 18, 1929. 